\title{
SMALL SAPHENOUS VEIN AND ACUTE VARICOSE THROMBOPHLEBITIS IN LOWER LIMBS
}

\author{
Sabadosh R.V. ${ }^{1}$, Pyptiuk O.V. ${ }^{1}$, Bohush A.Ye. ${ }^{2}$, Skrypko V.D. ${ }^{1}$, Ryziuk M.D. ${ }^{1}$, \\ Telemukha S.B. ${ }^{1}$, Khomyn D.Yu. ${ }^{2}$, Drahomyretskyi R.D. ${ }^{2}$
}

\begin{abstract}
In order to compare the role of the small and great saphenous veins (SSV and GSV) in the development of acute varicose thrombophlebitis in the lower limbs (AVTLL), 236 patients with thrombotic process in 250 limbs have been examined. The number of frequency of thrombosis among the limbs with reflux both in SSV and in GSV presented the role of these veins at AVTLL most objectively. According to this value, there was no statistically significant difference between SSV and GSV (p=0,669): 49,0\% (95\% CI 34,8-63,4\%) versus 45,1\% (95\% CI 31,1-59,7\%). This result showed that traditionally declared higher frequency of thrombosis in GSV among the total number of patients with AVTLL was caused by the more frequent presence of abnormal reflux in this vein solely. The frequency of thrombosis in the tributaries of GSV was significantly higher than the frequency of thrombosis in SSV tributaries, regardless of groups which were compared (all $\mathrm{p}<0.05$ ). Results of the study indicate that the role of SSV at AVTLL is often underestimated, and a thorough examination of the pathology of its system can improve the treatment effects of the patients with AVTLL.
\end{abstract}

Key words: acute varicose thrombophlebitis in lower limbs, small saphenous vein.

National Medical University (Ivano-Frankivsk), ${ }^{1}$ City Central Hospital (Ivano-Frankivsk) ${ }^{2}$

Рецензент - проф. В.П. Польовий

Buk. Med. Herald. - 2014. - Vol. 18, № 1 (69). - P. 87-91

Надійшла до редакції 22.12.2013 року

(C) Р.В. Сабадош, О.В. Пиптюк, А.С. Богуш, В.Д. Скрипко, М.Д. Ризюк,

С.Б. Телемуха, Д.Ю. Хомин, Р.Д. Драгомирецький, 2014

616.248-008.61-08-053.5

\section{C.I. Сажин}

\section{ЕФЕКТИВНІСТЬ СИМПТОМАТИЧНОЇ ТЕРАПІЇ НАПАДНОГО ПЕРІОДУ НЕАТОПІЧНОЇ ФОРМИ БРОНХІАЛЬНОЇ АСТМИ В ДІТЕЙ ШКІЛЬНОГО ВІКУ}

Буковинський державний медичний університет, м. Чернівці

\begin{abstract}
Резюме. У роботі досліджена ефективність полегшувального лікування бронхіальної астми в дітей. Встановлено, що школярам із фенотипом неатопічної бронхіальної астми притаманний більш виразний синдром бронхообструкції під час загострення порівняно 3 пацієнтами, які мають обтяжливий алергічний анамнез. Незважаючи на ідентичні стандартні схеми терапії у
\end{abstract}

Вступ. Сучасна концепція діагнозу бронхіальна астма (БА) грунтується на наступних складових: запалення, гіперсприйнятливість дихальних шляхів та наявність характерних респіраторних симптомів $[8,9]$. А різноманітність клінічних характеристик (стать, вік, раса, початок захворювання тощо) та прогностичних чинників (тривалість ремісії, ризики загострення та смертності), відсутність ефекту від стандартних принципів профілактичного лікування (стероїдна резистентність, токсичність швидко- та тривалодіючих селективних $\beta_{2}$-адреноміметиків, чутливість до анти-IgE), підтверджує думку про те, що астма - це синдром, який включає декілька варіантів або фенотипів [6, 12].

Історично бронхіальна астма була розподілена на дві форми - зовнішню (атопічну) та внутрішню (неатопічну) [4]. Проте у зв’язку з відсутністю чітких критеріїв атопічної та неатопічної БА, частота поширеності окремих форм у різних країнах є достатньо варіабельною [11].

(C) C.I. Сажин, 2014 групах порівняння, діти із неатопічним фенотипом захворювання характеризувалися більш виразними явищами обструкції дихальних шляхів під час усього періоду стаціонарного лікування.

Ключові слова: бронхіальна астма, діти, симптоматичне лікування, загострення.

Враховуючи, що паціснти з різними фенотипами захворювання потребують індивідуалізованих схем як симптоматичного, так і профілактичного лікування, на сьогодні продовжуються дискусії щодо доцільності включення до стандартів терапії бронхіальної астми окремих груп препаратів. Хоча лікувальна тактика під час нападу захворювання особливо не змінюється в пацієнтів із атопічним та неатопічним варіантами БА, проте, існують рекомендації щодо додаткового включення до плану терапії при неатопічній БА макролідних антибіотиків [7], а при атопічному фенотипові - більш широко використовувати інгаляційні глюкокортикостероїди (ІГКС) під час загострення [10]. Повсякчас, і перше, і друге твердження залишаються доволі дискусійними [5].

Мета роботи. Оцінити ефективність симптоматичної терапії в дітей, хворих на атопічну та неатопічну форми бронхіальної астми, для покращення індивідуалізованих схем лікування. 
Матеріал і методи. На базі пульмоалергологічного відділення обласної дитячої клінічної лікарні (м. Чернівці) обстежено 64 дитини, хворих на бронхіальну астму. Критеріями входження у дослідження вважали: вік дитини від 6 до 17 років, діагностовану персистувальну БА, тривалість хвороби не менше трьох місяців, наявність інформаційної згоди батьків та дітей. Критеріями невходження слугували: вік до 6 та старше 18 років; інтермітуюча БА, активне куріння більше десяти цигарок на день, використання препаратів, які могли б вплинути на результати досліджень, діти-сироти, наявність уроджених вад розвитку бронхів та легень, а також інших захворювань, що супроводжуються синдромом бронхообструкції.

Групоформувальною ознакою вважали наявність у дітей ознак атопії. Сформовано дві групи спостереження. До першої (I) групи увійшли 26 пацієнтів без ознак атопії, групу порівняння (II) склали 38 школярів із обтяжливим на алергічну патологію сімейним анамнезом та позитивними алерготестами з небактерійними алергенами.

Загальноклінічна характеристика пацієнтів клінічних груп наведена в таблиці 1 .

Відсутність вірогідних відмінностей за статтю, віком, тривалістю та тяжкістю захворювання, місцем проживання свідчила про коректно сформовані клінічні групи порівняння.
Тяжкість бронхообструктивного синдрому (БОС) при надходженні хворих до стаціонару під час загострення захворювання оцінювали за бальною шкалою [2]. Посилення проявів БОС відображалося зростанням оцінки за бальною шкалою.

Одержані результати дослідження аналізувалися за допомогою комп'ютерних пакетів «STATISTICA 6.0» StatSoft Inc. та Excel XР для Windows на персональному комп'ютері з використанням параметричних і непараметричних методів обчислення [1].

Оцінку ризику реалізації події обчислювали за атрибутивним (АР), відносним ризиками (ВР), співвідношенням шансів (СШ) [3].

Результати дослідження та їх обговорення. Терапія бронхіальної астми, незалежно від фенотипу, складається зі стандартних двох складових: симптоматичне (полегшувальне) та базисне (профілактичне) лікування [8]. Серед симптоматичних засобів, які використовують під час загострення, виділяють наступні групи: $\beta_{2}$-агоністи швидкої дії, інгаляційні холінолітики, глюкокортикостероїди (системні, топічні), метилксантини.

Установлено, що під час нападу БА, $\beta_{2}$ агоністи швидкої дії використовували в

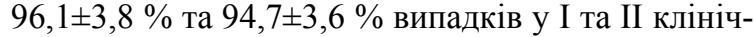
них групах відповідно $\left(\mathrm{P}_{\varphi}>0,05\right)$. Системні глю-

Загальна клінічна характеристика груп порівняння (M $\pm \mathbf{m})$

Таблиця 1

\begin{tabular}{|c|c|c|c|c|c|}
\hline \multirow{2}{*}{ Клінічні групи } & \multirow{2}{*}{$\begin{array}{c}\text { Кількість } \\
\text { дітей }\end{array}$} & \multirow{2}{*}{ Хлопчики } & Міські мешканці & $\begin{array}{c}\text { Тривалість хво- } \\
\text { роби }\end{array}$ & Середній вік \\
\cline { 3 - 6 } & & \multicolumn{3}{|c|}{$\%$} & \multicolumn{2}{|c|}{ роки } \\
\hline Перша & 26 & $53,8 \pm 9,8$ & $23,1 \pm 8,3$ & $5,4 \pm 0,7$ & $12,0 \pm 0,7$ \\
\hline Друга & 38 & $73,7 \pm 7,1$ & $39,5 \pm 7,9$ & $5,6 \pm 0,6$ & $11,7 \pm 0,5$ \\
\hline \multicolumn{2}{|c|}{$\mathrm{P}_{\mathrm{t}, \varphi}$} \\
\hline
\end{tabular}

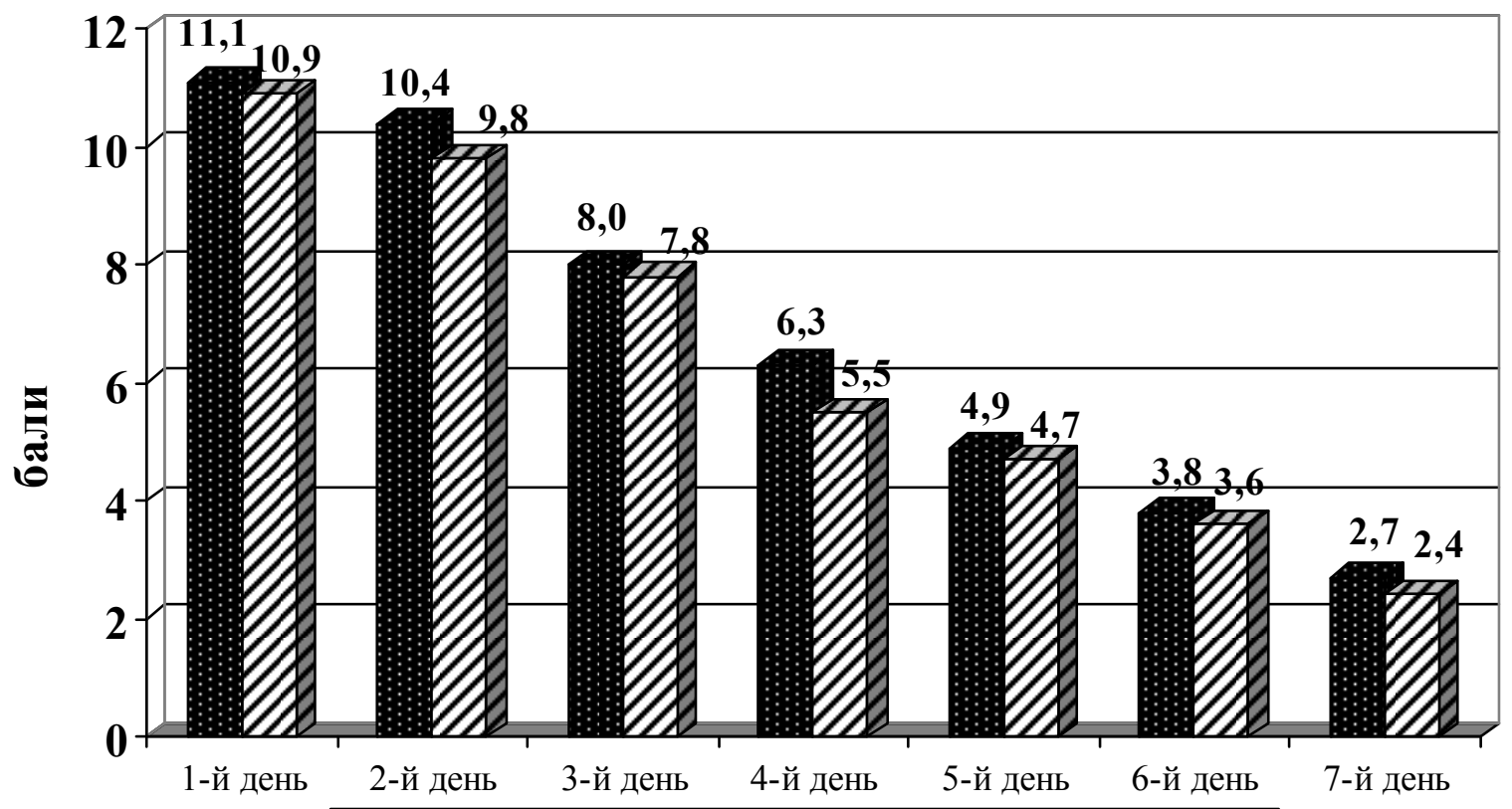

Фенотип неатопічної БА $\boldsymbol{\nabla}$ Фенотип атопічної БА

Рис. Бальна оцінка тяжкості бронхообструкції в нападному періоді бронхіальної астми у дітей груп порівняння 
Таблиця 2

Ризики більш виразної обструкції дихальних шляхів на тлі полегшувальної терапії в пацієнтів із неатопічним фенотипом бронхіальної астми

\begin{tabular}{|c|c|c|c|}
\hline Критерії & \multirow{2}{*}{$\mathrm{AP}, \%$} & \multirow{2}{*}{$\begin{array}{c}\text { ВР, \% } \\
(95 \% \text { ДІ) }\end{array}$} & \multirow{2}{*}{$\begin{array}{c}\text { СШ } \\
(95 \% \text { ДІ) }\end{array}$} \\
\hline Дні & & & \\
\hline Другий (вище 10 балів) & 14,8 & $\begin{array}{c}1,6 \\
(0,9-2,9)\end{array}$ & $\begin{array}{c}2,0 \\
(0,7-1,6)\end{array}$ \\
\hline Третій (вище 10 балів) & 2,2 & $\begin{array}{c}1,2 \\
(0,5-2,6)\end{array}$ & $\begin{array}{c}1,2 \\
(0,3-5,0)\end{array}$ \\
\hline Четвертий (вище 10 балів) & 9,0 & $\begin{array}{c}4,5 \\
(2,3-8,6)\end{array}$ & $\begin{array}{c}5,0 \\
(0,5-50,5)\end{array}$ \\
\hline П’ятий (вище 5 балів) & 4,4 & $\begin{array}{c}1,2 \\
(0,6-2,2)\end{array}$ & $\begin{array}{c}1,2 \\
(0,4-3,7)\end{array}$ \\
\hline Шостий (вище 5 балів) & 6,1 & $\begin{array}{c}1,5 \\
(0,7-3,0)\end{array}$ & $\begin{array}{c}1,6 \\
(0,4-6,1)\end{array}$ \\
\hline Сьомий (вище 3 балів) & 12,5 & $\begin{array}{c}2,2 \\
(1,2-4,0)\end{array}$ & $\begin{array}{c}2,5 \\
(0,6-10,1)\end{array}$ \\
\hline
\end{tabular}

кокортикостероїди застосовували у $73,7 \pm 7,1 \%$ i $73,1 \pm 8,7 \%$ спостережень у дітей з атопічним та неатопічним фенотипами захворювання $\left(\mathrm{P}_{\varphi}>0,05\right)$, серед яких у $5,3 \pm 3,6 \%$ та $11,5 \pm 6,2 \%$ в групах порівняння їх поєднували 3 ІГКС $\left(\mathrm{P}_{\varphi}>0,05\right)$. Метилксантини для зняття нападу БА призначали в $52,6 \pm 8,1$ \% дітям 3 атопічним фенотипом БА та у $42,3 \pm 9,7 \%$ пацієнтів із неатопічною формою хвороби $\left(\mathrm{P}_{\varphi}>0,05\right)$. Інфузійну терапію глюкозо-сольовими розчинами отримували $26,9 \pm 8,7 \%$ та $42,1 \pm 8,0 \%$ школярів I та II груп порівняння $\left(\mathrm{P}_{\varphi}>0,05\right)$. Достатньо «агресивну» комбінацію симптоматичних лікарських засобів, яка включала швидкодіючі $\beta_{2}$-адреноміметики, системні ГКС та метилксантини призначали дещо частіше пацієнтам із атопічним фенотипом БА $(31,6 \pm 7,5 \%)$ на відміну від дітей I клінічної групи $(15,4 \pm 7,1 \%)$, проте різниця не була достовірною $\left(\mathrm{P}_{\varphi}>0,05\right)$. Серед інших медикаментозних засобів, дещо частіше, діти 3 неатопічним фенотипом БА отримували антибактеріальну $(61,5 \pm 9,5$ \% проти 55,3 $\pm 8,1$ \% у II клінічній групі, $\left.\mathrm{P}_{\varphi}>0,05\right)$ та муколітичну $(88,5 \pm 6,3 \%$ проти $81,6 \pm 6,3 \%$ пацієнтів із атопічним варіантом захворювання, $\left.\mathrm{P}_{\varphi}>0,05\right)$ терапію. Пацієнтам, які увійшли в дослідження, антибактеріальна терапія призначалася здебільшого у формі таблеток та сиропів $(43,8 \pm 9,7$ \% проти $50,0 \pm 8,1 \%$ в I та II клінічних групах відповідно), внутрішньовенний шлях уведення даної групи препаратів викорис-

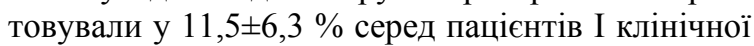
групи та у $13,2 \pm 5,5$ \% випадків школярам, хворих на атопічну БА (в обох випадках $\left.\mathrm{P}_{\varphi}>0,05\right)$. Парентерально препаратами вибору були антибіотики цефалоспоринового ряду, які призначали всім пацієнтам обох груп порівняння, які потребували внутрішньовенного уведення антибактеріальних лікарських засобів. Перорально застосовували цефалоспорини $(36,1 \pm 9,4$ \% проти $43,7 \pm 8,0 \%$ пацієнтів у групах 3 неатопічним та атопічним фенотипом, $\left.\mathrm{P}_{\varphi}>0,05\right)$ та макроліди $(11,5 \pm 6,3 \%$ проти 5,3 $\pm 3,6$ \% дітей I та II клінічних груп,
$\left.\mathrm{P}_{\varphi}>0,05\right)$. Антигістамінні препарати призначалися практично однаково дітям груп порівняння $(30,8 \pm 9,0 \%$ проти $34,2 \pm 7,7 \%$ відповідно, $\left.\mathrm{P}_{\varphi}>0,05\right)$. Відсутність вірогідних відмінностей між призначеною полегшувальною терапією в групах порівняння дозволила визначити їхню ефективність за динамікою клінічних симптомів у дітей з альтернативними імунологічними фенотипами БА.

Виразність бронхообструктивного синдрому в нападному періоді бронхіальної астми у школярів груп порівняння наведена на рисунку.

Таким чином, при госпіталізації та під час усього перебування в стаціонарі з приводу загострення БА, більш виразний синдром бронхообструкції спостерігався у пацієнтів із фенотипом неатопічної БА. Найбільшою різницею балів між групами порівняння характеризувався другий $(0,6$ бала) та четвертий $(0,8$ бала) день стаціонарного лікування, проте вона не була вірогідною між клінічними групами (в усі дні $\mathrm{P}>0,05$ ).

Діти з фенотипом неатопічної БА характеризувалися вищим ризиком виразнішого БОС (більше 10 балів) при госпіталізації: атрибутивний ризик становив $14,6 \%$, відносний ризик $(1,5$ при $95 \%$ ДІ 0,8-2,6) та співвідношення шансів $(1,9,95 \%$ ДІ 0,7-5,2).

Ризики більш виразної обструкції дихальних шляхів у пацієнтів I клінічної групи порівняно 3 дітьми, хворими на атопічну БА, на тлі регламентувальної симптоматичної терапії представлено в таблиці 2.

Наведені дані свідчать про незначне переважання на другу, четверту та сьому добу стаціонарного лікування пацієнтів I клінічної групи 3 більш виразними явищами бронхообструкції порівняно з атопічним фенотипом захворювання.

Підсумовуючи, варто зауважити, що лікування нападного періоду БА відповідає національним та зарубіжним настановам, і незалежно від фенотипу захворювання, основними лікарськими засобами, які застосовуються з метою симптома- 
тичної терапії, $є$ швидкодіючі $\beta_{2}$-адреноміметики, системні глюкокортикостероїди, метилксантини. Необгрунтовано велика кількість пацієнтів обох груп порівняння отримувала муколітичні препарати та антибіотики, причому частіше використовували антибактеріальні засоби цефалоспоринового ряду. Тяжкість бронхообструкції при надходженні та протягом усього терміну перебування в стаціонарі була незначно більшою в пацієнтів із неатопічним фенотипом БА. Ймовірно, дітям із неатопічною формою захворювання, які надходять до стаціонару з приводу загострення, варто призначати більш агресивну симптоматичну терапію з першого дня госпіталізації. У свою чергу, на етапі надання спеціалізованої медичної допомоги необхідно зменшити частоту призначення антибактеріальних препаратів пацієнтам із атопічним фенотипом БА.

\section{Висновки}

1. Пацієнти з фенотипом неатопічної бронхіальної астми характеризуються більш виразною обструкцією дихальних шляхів під час загострення порівняно $з$ школярами, хворими на атопічну форму хвороби.

2. Пацієнтам із неатопічною бронхіальною астмою під час загострення доцільно обмежити використання системних глюкокортикостероїдів, внаслідок недостатньої ефективності останніх при неатопічній астмі, проте більш широко використовувати інші симптоматичні лікарські засоби.

Перспективи подальших досліджень. Вивчити динаміку параклінічних показників у дітей 3 альтернативними імунологічними фенотипами під час загострення бронхіальної астми.

\section{Література}

1. Гублер Е.В. Вычислительные методы анализа и распознавания патологических процессов / Е.В. Гублер. Ленинград: Медицина, 1978. - 296 с.
2. Диагностика и лечение острых пневмоний и ОРВИ, осложненных БОС у детей раннего возраста / [Л.А. Безруков, Ю.Н. Нечитайло, С.А.Черевко и др.]; под ред. А.Ф. Мозолевского. - Черновцы, 1989. - 23 с.

3. Флетчер Р. Клиническая эпидемиология. Основы доказательной медицины / Р. Флетчер, С. Флетчер, Э. Вагнер; пер. с англ. С.Е. Бащинского [3-е изд.]. М.: Медиа Сфера, 2004. - 352 с.

4. Allergic and nonallergic asthmatics have distinct patterns of Tcell activation and cytokine production in peripheral blood and bronchoalveolar lavage / C. Walker, E. Bode, L. Boer [et al.] // Am. Rev. Respir. Dis. - 1992. Vol. 146. - P. 109-115.

5. Clinical Asthma Phenotypes and Therapeutic Responses [Електронний ресурс] / M. Zedan, G. Attia, M. M. Zedan [et al.] // ISRN Pediatrics. - 2013. - Режим доступу http://www.hindawi.com/isrn/pediatrics/2013/824781.

6. Different inflammatory phenotypes in adults and children with acute asthma / F. Wang, X.Y. He, K.J. Baines [et al.] // Eur. Respir. J. - 2011. - Vol. 38. - P. 567-574.

7. Effect of clarithromycin on acute asthma exacerbations in children: an open randomized study / I. Koutsoubari, V. Papaevangelou, G.N. Konstantinou [et al.] // Pediatric Allergy and Immunology. - 2012. - Vol. 23. - P. 385-390.

8. Global Strategy for Asthma Management and Prevention (updated 2012) [Електронний ресурс] // Global Initiative for Asthma, 2012. - Режим доступу: http:/ www.ginasthma.org/local/uploads/files/ GINA Report 2012 Feb13.pdf.

9. International consensus on (ICON) pediatric asthma / N.G.Papadopoulos, H. Arakawa, K.-H. Carlsen // Allergy. - 2012. - Vol. 67. - P. 976-997.

10. Response to budesonide among atopic and non-atopic infants/ preschoolers with recurrent wheezing / L. Campusano, M. Pastenes, C. Fontecilla [et al.] // Allergologia et immunopathologia. - 2010. - Vol. 38, № 1. P. 31-36.

11. Risk factors for atopic and non-atopic asthma in a rural area of Ecuador / A.L. Moncayo, M. Vaca, G. Oviedo [et al.] / Thorax. - 2010. - Vol. 65. - P. 409-416.

12. Weiss S.T. New approaches to personalized medicine for asthma: Where are we? / S.T. Weiss // J. Allergy Clin. Immunol. - 2012. - Vol. 129. - P. 327-334.

\section{ЭФФЕКТИВНОСТЬ СИМПТОМАТИЧЕСКОЙ ТЕРАПИИ ПРИСТУПНОГО ПЕРИОДА НЕАТОПИЧЕСКОЙ БРОНХИАЛЬНОЙ АСТМЫ У ДЕТЕЙ ШКОЛЬНОГО ВОЗРАСТА}

\section{С.И. Сажин}

Резюме. В работе исследована эффективность симптоматического лечения бронхиальной астмы у детей. Установлено, что для школьников с фенотипом неатопической бронхиальной астмы свойственно более выразительный синдром бронхообструкции во время обострения сравнительно с пациентами, у которых отягощенный аллергический анамнез. Несмотря на идентичные стандартные схемы терапии в группах сравнения, дети с неатопическим фенотипом болезни характеризовались более выраженными явлениями обструкции дыхательных путей во время всего периода стационарного лечения.

Ключевые слова: бронхиальная астма, дети, симптоматическое лечение, обострение. 


\section{THE EFFICACY OF THE SYMPTOMATIC THERAPY OF THE NON-ATOPIC BRONCHIAL ASTHMA ATTACK IN SCHOOLCHILDREN}

\section{S.I. Sazhyn}

Abstract. The effectiveness of symptomatic treatment of bronchial asthma in children has been studied. It has been found that patients with non-atopic asthma phenotype were characterized by more severe bronchial obstruction during exacerbations compared with atopic patients. Children afflicted with nonatopic phenotype of the disease were characterized by more pronounced signs of airway obstruction during the whole hospitalization period despite the identical standard regimens in the comparison groups.

Key words: bronchial asthma, children, symptomatic treatment, exacerbation.

Bukovinian State Medical University (Chernivtsi)

Рецензент - проф. Т.В. Сорокман

Buk. Med. Herald. - 2014. - Vol. 18, № 1 (69). - P. 91-95

Надійшла до редакції 13.11.2013 року

(C) C.I. Сажин, 2014

УДК 616.13-005.4-089.12:617.58

\section{P.В. Салютін}

\section{ЛІКУВАННЯ ХРОНІЧНОЇ ІШЕМЇ̈ НИЖНІХ КІНЦІВОК ІЗ ЗАСТОСУВАННЯМ МЕТОДУ КЛІТИННОЇ НЕПРЯМОЇ РЕВАСКУЛЯРИЗАЦЇ}

Координаційний центр трансплантації органів, тканин та клітин, м. Київ

\begin{abstract}
Резюме. Проблема лікування хворих із нереконструктабельним ураженням периферичного артеріального русла є актуальною та до кінця не вирішеною. Результати проведеного експериментального дослідження зі змодельованою ішемією кінцівки довели доцільність та ефективність застосування прогеніторних клітин фетальної печінки 3 метою активації регенераторновідновних процесів та ангіогенезу.

Метою наукової роботи було дослідження клінічної ефективності методу клітинної «непрямої» реваску-
\end{abstract}

Вступ. Враховуючи велику кількість випадків захворювання на хронічну ішемію нижніх кінцівок, що зумовлює високий відсоток летальності та інвалідизації пацієнтів, особливо старшого віку, необхідний пошук нових методів лікування цієї хвороби. В умовах ураження дистального артеріального русла та мікроангіопатії, якщо виконана раніше «пряма» реваскуляризація визнана неефективною або відсутні покази до іiі виконання, важливого значення набувають методи «непрямої» реваскуляризації $[1,4]$.

Одним із напрямів сучасних досліджень $€$ використання клітинних технологій $з$ метою активації процесів ангіогенезу на рівні колатеральної артеріальної сітки, зокрема за допомогою уведення стромальних автологічних стовбурових клітин кісткового мозку та жирової тканини [3, 6]. Однак широке клінічне використання клітин кісткового мозку та жирової тканини обмежено певними технологічними проблемами та низьким ляризації в комплексному лікуванні хворих на хронічну ішемію нижніх кінцівок.

Розроблена методика застосування прогеніторних клітин фетальної печінки людини в комплексному лікуванні ішемії нижніх кінцівок $\epsilon$ ефективним і доступним методом «непрямої» реваскуляризації. Цей метод показаний до використання у пацієнтів, яким неможливо виконати реконструкцію судинного русла, в осіб літнього віку та з вираженою супутньою патологією.

Ключові слова: хронічна ішемія, непряма реваскуляризація, прогеніторні клітини, фетальна печінка.

потенціалом трансдеференціювання дорослих (abult) мезенхімальних клітин [5]. Прогеніторні клітини фетальної печінки людини 6-8 тижнів гестації експресують CD 34+, CD 38-, CD 45Ra ${ }^{\text {low }}$, $\mathrm{CD} 71^{\text {low }}$, що свідчить про високий потенціал трансдиференціювання до ангіобластів та ендотеліоцитів - основної складової капіляра, зумовлюючи значну потенцію до стимуляції процесів ангіогенезу, ніж автоклітини кісткового мозку або жирової тканини [2], та має підтвердження результатами експериментального дослідження, проведеного на щурах.

Таким чином, застосування «непрямої» клітинної реваскуляризації з використанням клітинних культур фетального походження, 3 метою стимуляції ангіогенезу за умов ішемії, має теоретичне та експериментальне підгрунтя та $є$ досить перспективним напрямком науково-практичних розробок. 